\title{
The Emergence of a Polish National Dress and Its Perception
}

\begin{abstract}
This article examines the evolution of an early modern Polish national dress called the kontusz ensemble. It differed from the fashion of the West both in cut and look. The garment was mostly worn by the Polish nobility and was one of the distinguishing features of this estate and its ideology. It started forming in the sixteenth century, when knighthood was gradually abandoned and eventually replaced by an estate of landowners mainly involved in agriculture. These noblemen identified with the Sarmatian tradition and tried to prove their Sarmatian origins. Throughout the early modern period this garment was subject to modifications, but it retained its essential Eastern form.
\end{abstract}

\section{Introduction}

The Polish national dress, the kontusz ensemble, differed from the fashion of Western Europe both in its cut and its accessories. It comprised a group of garments that might be defined as Eastern European. These garments belonged to the szlachta - the Polish nobility - and were one of the distinguishing features of this estate and its ideology. The term "national dress" first appeared only in the late eighteenth century, among the patriotic slogans of the Four-Year Sejm (1788-1792). However, it did not emerge out of nowhere: for more than two centuries the kontusz ensemble had functioned as the dress of the noblemen of the Polish-Lithuanian Commonwealth. To understand the significance of this attire it is necessary to consider some aspects of the szlachta habitus, the nobility's particular way of viewing the world and expressing emotions.

This article presents the development of the dress of the Polish nobility from the fifteenth to the nineteenth century. First, it describes the dress of medieval Polish knights; second, it discusses the emergence of the Sarmatian ideology and dress and the changes it underwent in the eighteenth century; finally, it concludes with a glance toward the nineteenth-century perception of the Sarmatian tradition. The article focuses on male dress, because female dress developed very differently, being strongly influenced by Western fashion. ${ }^{1}$

1 For more information on Polish female dress see: Maria Gutkowska-Rychlewska: Historia ubiorów. Wrocław 1968, 423-436, 529-541, 688-706, 768-804. 


\section{Medieval Forerunners}

In medieval Poland, like elsewhere in Europe, it was important for people to show that they belonged to a certain estate, were of a certain social rank, or had a certain occupation. The szlachta was a direct successor of the knightly estate, so its essence was defined by the craft of war. In the Middle Ages, we find a number of examples of attempts at sartorial self-determination through a combination of Western and Eastern elements of fashion.

If we were to look for a garment that was representative of Polish elites already in the medieval period, we would have to point to the szuba, a kind of a long overcoat made from expensive textiles. The szuba came to Poland from the east in the fourteenth century, via Lithuanian and Ruthenian influences. ${ }^{2}$ It was popular among European elites of the period generally to combine different regional garments: from the West (especially German and Italian fashion), from the East, and from the South (particularly from Hungary). Hungarian dress was relatively widespread and was recognized in Italy and elsewhere. In the eyes of some foreigners, Polish clothing was seen as something of a "corrupt" form of Hungarian attire. ${ }^{3}$

The Polish national costume began to acquire its main distinctive features already in the Middle Ages, when the mighty Byzantine Empire still thrived in the East. The Byzantine court in Constantinople, with its splendor inherited from the Roman Empire and enriched through relations with Persian Sasanians and Abbasid Muslims, became the source of cultural inspiration for Christians and Muslims alike. ${ }^{4}$ Constantinople served for other countries as a source of conceptual models, such as forms of Oriental dress. As a result, the basic concept of a costume consisting of a modified tunic with a coat worn over it was established in the Byzantine Empire. The costumes made according to this basic form took on various shapes in different countries, depending on local tradition

2 Danuta Poppe: Szuba średniowieczna w Polsce i na Rusi, in: Maria Dembiński (ed.): Szkice z dziejów materialnego bytowania społeczeństwa polskiego. Wrocław 1989, 11-39.

3 Giulinao Passero: Giuliano Passero cittadino napoletano o sia prima pubblicazione in istampa, che delle Storie in forma di Giornali, le quali sotto nome di questo autore finora erano andate manoscritte. Naples 1785, 242; Władysław Pociecha: Królowa Bona (1494-1557). Czasy i ludzie odrodzenia, vol. 1. Poznań 1949, 203.

4 Beata Biedrońska-Słotowa: Polski ubiór narodowy zwany kontuszowym. Cracow 2005, 18-28; Ernst H. Kantorowicz: Gods in Uniform, in: id.: Selected Studies. New York 1965, 7-24; André Grabar, L'empereur dans l'art Byzantin. London 1971, 48, pl. IV; Elizabeth Piltz: Le costume official des dignitaries byzantins à l'epoque Paléologue. Uppsala 1994. 
and the intensity of contacts with the East. ${ }^{5}$ A notable distinction thus began to appear between the types of dress worn in Eastern Europe, particularly in Poland, and the completely different styles of dress worn in Western Europe. ${ }^{6}$

\section{The Emergence of a Polish National Costume}

The term "national costume" as used to describe the kontusz ensemble relates to the Polish nation in the early modern sense; that is, "nation" here refers exclusively to the Polish nobility. The emergence of a particular form of dress in Poland was closely connected to the development of the early modern Polish state, which was increasingly governed by a distinguished social group comprised of landowners of varying degrees of wealth. The sixteenth century was a period of profound transformations in Polish society. The knighthood was then being abandoned in line with the growth of landed estates established by those who preferred to occupy themselves with farming and the profits it generated. The group of landed gentry began to grow. ${ }^{7}$ Nobles made up ten percent of the population, a much larger proportion than in most parts of Western Europe. With the emergence of a political system that had the nobility at the center of political representation, a need arose for a suitable ideology to reflect this group's growing power and influence. For the Polish nobility Sarmatism became such an ideology.

With the ideology of Sarmatism the szlachta defined itself as a group that was not only better than but also essentially different from the rest of the population. Following the theses put forward by certain Polish Renaissance authors, attempts were made to demonstrate the Polish gentry's historical origins in, and contemporary similarity to, the ancient Sarmatians, migrating pastoral

5 Patricia L. Baker et al.: Silk for the Sultans. Ottoman Imperial Garments from Topkapi Palace. Milan 1996; Tim Dawson: A Tunic from Eastern Anatolia, in: Costume 36 (2002), 93-99; Corina Nicolescu: Istoria Costumului de Curte in Ţările Romane Secolete XIV-XVIII. Bucharest 1970; Hermann Goetz: The History of Persian Costume, in: Alexander Upham Pope and Phyllis Ackerman (eds.): A Survey of Persian Art, from Prehistoric Times to the Present, vol. 3. New York 1938, 2227-2256.

6 It should be noted that Poland had trade, diplomatic and personal ties with the Byzantine state already in the twelfth century. Maria, the daughter of Sviatopolk Iziaslawich, the Grand Prince of Kiev and Byzantine princess Barbara Komnena, married Piotr Włostowicz (d. 1153), a palatine of the Polish prince Bolesław III Wrymouth and brought with her richly decorated costumes, see: Gutkowska-Rychlewska, Historia ubiorów, 276-277.

7 Ibid., 37. 
tribes of Iranian origin. ${ }^{8}$ The core tenet of the Sarmatian myth held that the ancestors of the Polish nobility conquered East-Central Europe in the "old times", as Jan Długosz, a Polish chronicler of the fifteenth century put it. The szlachta glorified its own way of living, fundamentally opposed to urban living and hostile towards foreign influence.

With the emergence of Sarmatism the myth of a particular and ancient Polish tradition was born. Although we do not really know how it evolved, its consequences have lasted for centuries. In this way, the sixteenth century, the time of flourishing humanist ideas, also saw the birth of a concept that provided the basis for national chauvinism and, later, xenophobia. (It should be noted, however, that the internally inconsistent Sarmatian humanism provided an example of openness to others, including people of other religions.) It was also at this time that the Polish "Sarmatians", as the adherents of Sarmatism among the gentry came to be called, discovered the appeal of the so-called "golden liberty", the political system of the Polish-Lithuanian Commonwealth after the Union of Lublin (1569), in which all nobles, irrespective of their social status, elected the king, controlled the legislature, and enjoyed substantial legal rights. The concept may sound glorious, but some historians have argued that over time it led to a growing anarchy in the country's political life. ${ }^{9}$ The spirit of knighthood still predominated at the beginning of the sixteenth century, but it was not always ideologically compatible with the Sarmatian attitude, which was expressed mainly in the desire to accumulate goods and to exercise political power. Parallel with the Sarmatian tradition grew the concept of the Polish gentry as heirs of the citizen virtues of the ancient Romans. Some people, however, lamented the loss of the knightly spirit and criticized "farmerization", the quiet rural life away from the centers of humanism. This Sarmatian attitude, together with the landlords' lifestyle, resulted in gradual changes of attire and the emergence of the distinctive male dress that later became known as the kontusz ensemble. ${ }^{10}$ This gradual transformation of a knight into a member of the landed nobility, fueled by the Sarmatian ideology, ${ }^{11}$ resulted in male dress becoming

8 Tadeusz Ulewicz: Około genealogii sarmatyzmu (spóźnione podjęcie nieprzedawnionej dyskusji), in: Pamiętnik Stowiański 1 (1949), 101-114; Tadeusz Mańkowski: Genealogia sarmatyzmu. Warsaw 1946; Tadeusz Ulewicz: Sarmacja. Studium z problematyki stowiańskiej XV i XVI w. Cracow 1950.

9 Maria Bogucka: The Lost World of the "Sarmatians". Custom as the Regulator of Polish Social Life in Early Modern Times. Warsaw 1996.

10 Beata Biedrońska-Słota: Sarmatism. Dreams of Power. Cracow 2010.

11 See for example, Maciej z Miechowa (1456-1523): Descriptio Sarmatiarum Asianae et Europianae et eorum quae in eis continent. Cracow 1521. 
increasingly similar to that worn in the Persian and Ottoman Empires. This kind of costume soon became a distinctive tool of the gentry's consolidation. It marked its wearer's social affiliation and even, according to some observers, expressed the group's worldview. It testified to its wearer's outlook on life, and was also a means of propaganda. It declared one's attachment to tradition, which often meant benightedness and provincialism.

In Poland the spread of male attire sewn in accordance with Persian and Ottoman fashion was facilitated not only by the Sarmatian tradition but also by the presence of original Oriental costumes and their integration into the Polish lifestyle. ${ }^{12}$ Original costumes from the Orient, mostly from the Ottoman Empire, were brought to Poland as honorary costumes, usually given to diplomats as a sign of respect. Known as hilat, ${ }^{13}$ these costumes were sewn from the richest silk fabrics, with entwined gold and silver threads and decorated with sophisticated patterns, often designed by miniature-painters. An oft-cited example comes from a letter of 1549, written by the wife of Sultan Suleyman, Hurrem Sultan (also known as Roxelana), to King Sigismund II Augustus: “[. . .] To not leave the letter empty [...] I sent two pairs of trousers with a shirt, with a belt for them, six scarves and a towel." ${ }^{14}$ An envoy of King Sigismund II Augustus noted in 1557 that during the farewell ceremony "a gold-threaded lower dress was brought and another broad one to put over, also gold-threaded, accompanied by several pieces of kemkha [silk textile]". ${ }^{15}$ He further remarked that "after the banquet Chaush Pasha assisted the envoy and a couple of his men to a separate room where, as a sign of favor, they are dressed in varicolored gold-threaded kaftans, with various figures of birds and other creatures". ${ }^{16}$ In a similar way, Sefer Muratowicz, a diplomat sent to Persia by King Sigismund III in 1601, was given a green damask żupan, with a gold-threaded dress on top. ${ }^{17}$ One may assume that ready-made Oriental costumes, brought to Poland and used on certain important occasions to demonstrate

12 Przemysław Mrozowski: Ubiór jako wyraz świadomości narodowej szlachty polskiej XVI-XVIII wieku, in: Anna Sieradzka and Krystyna Turska (eds.): Ubiory w Polsce. Materialy III Sesji Klubu Kostiumologii i Tkaniny Artystycznej przy Oddziale Warszawskim Stowarszyszenia Historyków Sztuki. Warsaw 1994, 19-27.

13 Patricia L. Baker: Islamic Textiles. London 1995, 93.

14 Zygmunt Abrahamowicz and Ananiasz Zajączkowski (eds.): Katalog dokumentów tureckich: dokumenty do dziejów Polski i krajów ościennych w latach 1455-1672. Warsaw 1959, 103.

15 Józef Ignacy Kraszewski: Podróże i poselstwa polskie do Turcji. Cracow 1869, 20.

16 Łukasz Gołębiowski: Ubiory w Polsce od najdawniejszych czasów aż do chwil obecnych, sposobem dykcjonarza ułożone. Cracow 1861, 132.

17 Sefer Muratowicz: Relacya Sefera Muratowicza, obywatela warszawskiego, od Zygmunta III, króla polskiego, dla sprawowania rzeczy wysłanego do Persyi $w$ r. 1602. Rzecz z starego rękopisma wybrana y teraz dopiero do druku podana. Warsaw 1777. 
splendor and magnificence, had an impact on the preferences and tastes of Polish noblemen.

In addition to textual and visual sources confirming the influx of Oriental costumes to Poland, we find also material remains. When brought to Poland, Oriental costumes were often reworked into liturgical vestments and adapted for the Church's needs, though we cannot be sure whether these costumes were first worn or were turned right away into liturgical vestments. This adaptation, however, probably explains why original Oriental costumes from before the nineteenth century have not been preserved in any Polish collection. What is preserved, however, are original precious textiles in secondarily-assembled paraments. ${ }^{18}$

The richness of Persian and Ottoman textiles, costumes, armor, and jewelry appealed to the Sarmatians' taste. Colorful clothing, furs, and jewels were also calculable capital investments for the szlachta. Contacts with neighboring countries had had a significant influence on this taste. Clergyman and writer Szymon Starowolski (1588-1650) mentions that wide and sweeping fur coats (lined with sables and ermines) were borrowed from the Russians, coats for soldiers from the Tatars, and short, very tight jackets, wide shoes, leather greaves, and coats from the Swedes. ${ }^{19}$ In France, England, or the Netherlands such exotic items as fur coats were most often a decorative element, having the status of an oddity; in Old Poland, by contrast, Oriental garments and accessories were present as an integral part of everyday life.

Among Western observers, Polish fashion and love of exotic things evoked rather critical reactions. Frenchmen found it was odd to wear such long, heavy garments lined with fur, given the climate. In France, fashion was dictated by the court centered around the king. In the eyes of foreigners, the Polish lifestyle, in its fashion and its feasts, resembled Persian customs. In this era of European expansion, Europeans felt superior to "savage, uncivilized" people. For masquerades and balls it was common to dress up as exotic figures, and alongside Indians, Arabs, Chinese, Persians, and Turks, there were Polish and Muscovite costumes, too, an expression of the negative assessment of Sarmatian fashion and taste..$^{20}$ Karol Ogier, a French writer and diplomat, wrote in 1635 that praying Polish voivodes wearing national clothes reminded him of Eastern magi bowing before baby Jesus "with great grandeur and in a long suite of courtiers

18 Magdalena Piwocka: A Turkish Hilat at Jasna Góra, in: Arma Virumque Cano. Profesorowi Zdzisławowi Żygulskiemu jun. w osiemdziesięciopięciolecie urodzin. Cracow 2006, 343-350.

19 Janusz Tazbir: Kultura szlachecka w Polsce. Rozkwit-upadek-relikty. Poznań 1998, 158.

20 Ibid. 169; Larry Wolff: Inventing Eastern Europe. The Map of Civilization on the Mind of the Enlightenment. Stanford 1994, esp. chapter 1. 
and camels". ${ }^{21}$ Jakub Sobieski had an audience with Pope Paul V in 1612, during which his servant was terribly drunk and eventually tripped, scattering devotional items. Allegedly, the pope was amused and asked who the servant was: "a baptized Turk or Tatar?"22 An account of the arrival of the Polish envoy to Paris in 1645 by a French woman, Francesca de Motteville, also expresses a Western person's view of Sarmatian pomp: “it has shown the ancient glory that was taken by the Persians from the Medes [...] Although Scythians were never famous for indulging pleasures, their descendants, close neighbors of the Turks today, seem to be striving to imitate the grandiosity and richness of the Turkish sultan.”23 Polish lords were

wearing silks interwoven with gold and silver. The textiles of their clothes were so costly, so beautiful, in such vivid colors, that they tore the eyes. On the caftans jewels shimmered. It has to be said however that among all of this richness the splendor was very close to the great barbarism; they do not wear underwear at all, they sleep not on bed sheets but on animal hides, which they wrap themselves with [.. . ] their heads are shaven, only on the top is a small flock of hair hanging down to the back. ${ }^{24}$

The Polish national costume that developed in the seventeenth century was highly ornate, colorful, and richly adorned with jewelry. It consisted of a zupan, a long front-buttoned garment, most often crimson in color, similar to Turkish and Persian dress, and a delia, a long overcoat, whose shape - with its long, dangling, decorative sleeves reaching to the floor, thrown to the back and hanging along the line of the back - closely imitated the dress used at the sultan's court. The delia was often lined with fur and had a wide fur collar. In the front it was often braided with haberdashery tapes. The kontusz, a kind of caftan worn over the zupan, first appeared in the seventeenth century and grew steadily in popularity thereafter. The head was dressed in a kotpak - a high hat with a wide fur band and a decorative bundle of heron or ostrich feathers fixed in a szkofia, a kind of brooch. The whole ensemble was decorated with jewelry in the form of golden or silver haw-shaped or hazelnut-shaped buttons, meticulously decorated with granulation and filigree, and set with gems. A necessary addition to this Sarmatian costume was a karabela - a Turkish-style saber hanging on straps at the left side. Expensive Polish calf-length shoes, made from yellow or red leather, indicated the nobleman's wealth. The haircut was

21 Karol Ogier: Dziennik podróży do Polski 1635-1636, vol. 1. Gdańsk 1950, 173.

22 Jakub Sobieski: Peregrynacyja po Europie (1607-1613). Droga do Baden (1638), edited by Józef Długosz. Wrocław 1991, 206.

23 See Françoise de Motteville: Anna Austriaczka i jej dwór. Warsaw 1978, 90.

24 Ibid., 91. 
also distinctive: fashionable Sarmatians shaved their heads high, leaving only a central strip of hair running along the skull (Figure 1). This haircut quickly became a principal sign of belonging to the social group, much as facial hair was shaped according to fashion. Jędrzej Kitowicz (1728-1804), a historian and memoirist, wrote: "one who dressed as a Pole had to wear a moustache, and could not shave it without making a clown of himself." 25

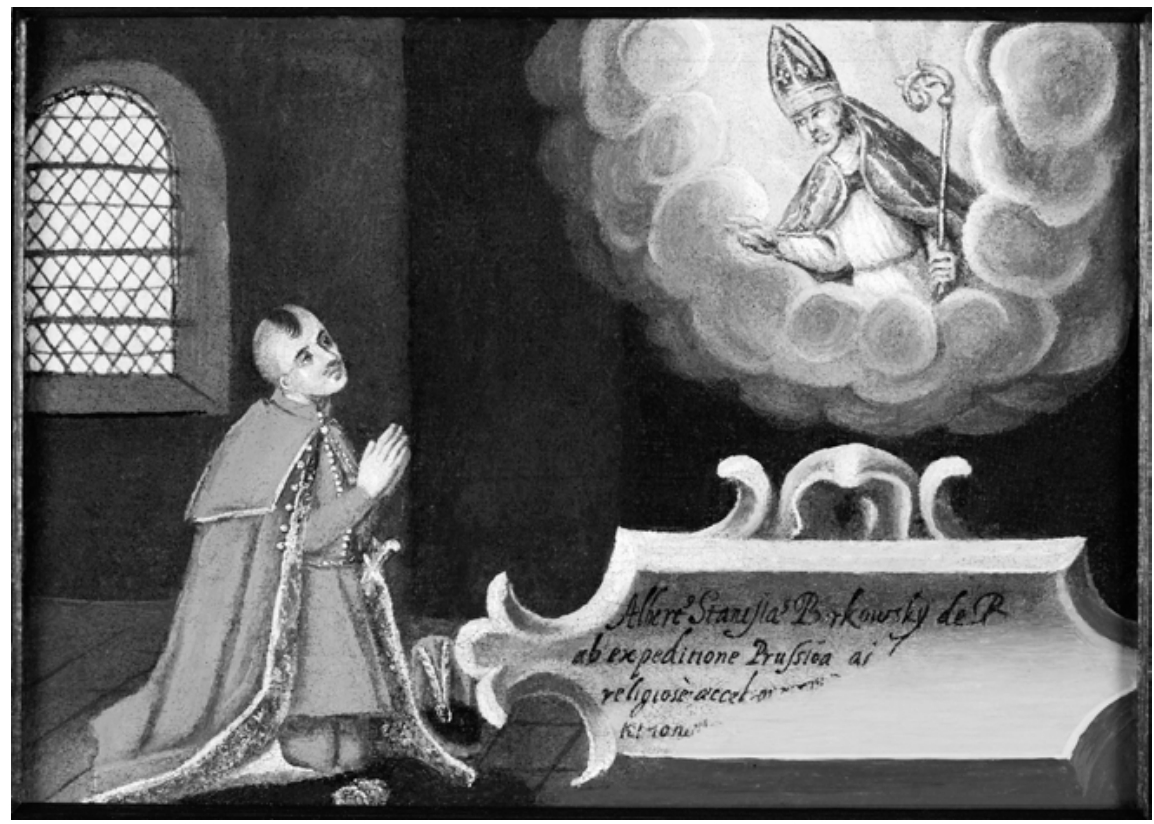

Figure 1: Votive painting of Albert Stanisław Borkowski of Borków, c. 1631, St. Thomas and St. Stanisław Church in Piotrawin. Photo by Beata Biedrońska-Słota.

The dress of Krzysztof Zbaraski, as represented in his portrait in the Lviv Painting Gallery, is a good illustration of this phenomenon. Zbaraski (ca.1580-1627) acted in various roles as a statesman of Poland, including being sent abroad as a diplomat on various missions (Figure 2). The best known of these is his mission to Istanbul to the court of Sultan Mustafa I in 1622-1624 to negotiate the liberation of Polish knights who had been taken captive, together with their commander, field hetman Stanisław Koniecpolski, after the defeat at Cecora (in Moldavia) in 1620. Zbaraski also wanted to convince the Turkish side that Poland had not

25 Jędrzej Kitowicz: Opis obyczajów za panowania Augusta III. Wrocław 1951, 465. 


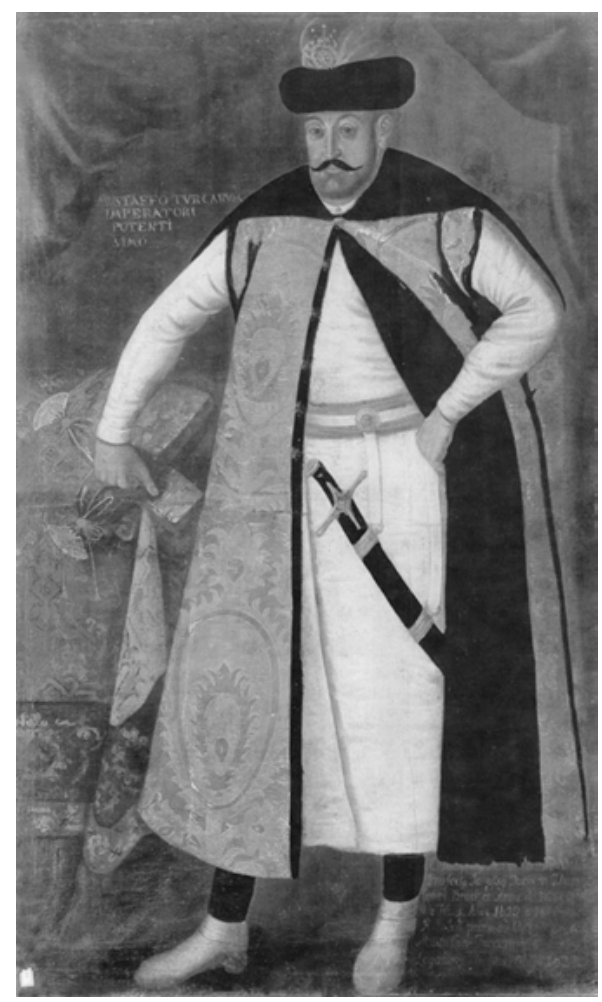

Figure 2: Portrait of Krzysztof Zbaraski, c. 1627, Lviv Painting Gallery. Photo by Beata Biedrońska-Słota.

promised to pay a war tribute. He departed from Końskowola on September 9, 1622, and returned there on Easter, 1623, having successfully completed the mission that would later grow into a legend. ${ }^{26}$ As part of his efforts to make the mission effective, Zbaraski had gone to the Sultan's court wearing a costume that demonstrated his high rank and his noble stance, as shown in his painted image. Zbaraski is shown in the portrait in a long white żupan of mid-calf length, girded with a soft red silk sash and a narrower leather belt supporting saber slings on which a karabela hangs. The żupan is buttoned under the neck, with a clasp adorned by a large red gem. A splendid delia worn on the żupan is made of Turkish gold lamé and silver lamé fabric of the type known as serâser, with

26 Samuel Twardowski: Przeważna legacyja Krzysztofa Zbaraskiego od Zygmunta III do sottana Mustafy. Warsaw 2000, 295. 
a large-scale pattern of golden peacock feathers on silver background. The whole delia is lined with fur and has a large straight fur collar and very long sleeves thrown to the back and is fastened with decorative large buttons placed on the margin of one fly. Short shoes made of yellow leather reach above the ankles. The dress is complete with a splendid kotpak on the head, which has a wide fur surround and a rich szkofia decorated with rubies and supporting a very high bunch of feathers. According to a written description by Samuel Twardowski, ${ }^{27}$ the magnificent crest especially attracted attention, so that even the sultan himself wanted to buy it. It deserves special attention that the costume worn by Zbaraski in the portrait today may be considered at first glance a Turkish dress. His attire suggests that in the seventeenth century this costume was already such an integral element of Polish tradition that the Polish envoy had chosen to wear it on his diplomatic mission to the Ottoman Empire. The picture presents a synthesis of all the distinctive characteristics of the epoch and provides evidence that Oriental costumes had become part of Polish tradition.

Another episode in the royal court demonstrates the extent to which Polish costumes inspired by Oriental fashion were seen both as Oriental dress and as typically Polish, already in the seventeenth century. When Tatar troops were expected to join the Crown's army in 1654, the Court decided to fund and prepare costumes for these Tatars and their commanders. These costumes, which were given to the Tatar envoys, appeared as typically Polish: kontuszes, żupans, ferezjas (long overcoats), and hats, all made to Oriental fashion of expensive western materials. ${ }^{28}$ Another example was the preparation, at the wish of the king, of a żupan and a ferezja from exquisite cloths for the Tatar envoy Dedesh Aga and his numerous retinue, who were sent by the Crimean Khan in $1655 .{ }^{29}$ Similar gifts were given to the Tatar envoy Alisz Aga, sent to the king in 1655. He received magnificent dresses from Venetian velvet lined with fur and a kontusz with golden loops and braiding. ${ }^{30}$ A dress assembled in this way also made a strong impression on foreign observers already in the seventeenth century. The Irish physician of John III Sobieski, Bernard O'Connor, recorded in his memoir: "Sobieski used to wear a native dress and this is different from other European dresses and incomparably more solemn." 31

\section{Ibid.}

28 Archiwum Główne Akt Dawnych (Central Archives of Historical Records in Warsaw) [AGAD], Archive of the Treasury of the Crown III, vol. 5, 680-681.

29 Ibid., 699a.

30 Ibid., 701.

31 Quoted from Julian Ursyn Niemcewicz: Zbiór pamiętników o dawnej Polsce, in: Julian Ursyn Niemcewicz (ed.): Dzieła. Cracow 1883-1886, vol. 4, 395. 
The form of the Polish costume underwent modifications during subsequent centuries, but its basic form as influenced by Oriental dress was maintained. By the middle of the eighteenth century it attained its classical form, consisting of a żupan, a kontusz, and a delia. The form of the kontusz had changed and acquired its distinctive split sleeves. The kontusz was invariably girded at the waist with a decorative silk sash, gold lamé or silver lamé, woven using a large amount of golden and silver threads (Figure 3). Like most elements of the costume, the sash was of Oriental provenance too.

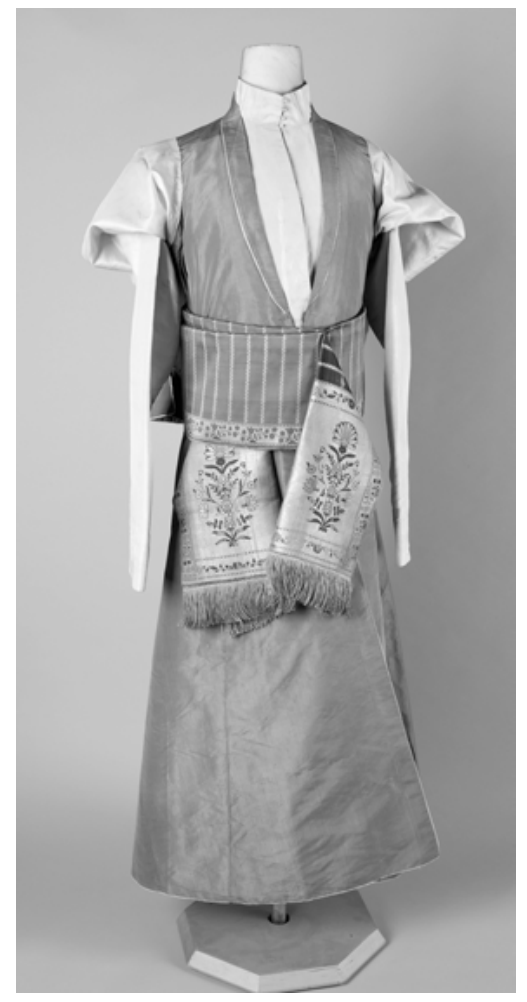

Figure 3: Kontusz costume, c. 1770, National Museum in Cracow.

\section{Differences within Polish Nobility: The Myth of Equality}

The Polish costume described above appears mostly to be that of an ideal type of the wealthy Polish nobility. However, one should not forget that the nobility was 
not a homogeneous group. The szlachta proclaimed the equality of its estate in the sixteenth century and never created any formal hierarchy; thus, in theory, every nobleman had the same status, including the wealthiest magnates, and this alleged equality was regarded as the foundation of the nobility's democracy and free elections. However, social differences among Polish noblemen remained, which were also visible in their costumes, though less in terms of styles than in the embellishments that were added and the quality of the fabrics that were used.

In the seventeenth century, another line of conflict emerged, between the szlachta and the king. The conflict between the szlachta and King Sigismund III Vasa, which lasted from 1606 to 1608, was called the war between czupryna and ponta, that is, between the Polish hairstyle described above and the Spanish style of beard trim. Sigismund III, who usually dressed in western (Spanish) fashion, had a pointy goatee. One foreign observer remarked that the king's Spanish attire distinguished him from his subjects, the Polish szlachta, who did not like this attempt at distinction. The king was supposed to be the king of kings after all, meaning a member of Polish nobility. The king's trusted man Marcin Wolski was also criticized for wearing foreign clothing. ${ }^{32}$ Sigismund III wore Polish dresses in certain situations to gain the support of the szlachta, as for example during the siege of Smoleńsk (1609-1611). ${ }^{33}$ A similar story is told of Jan II Kazimierz (1609-1672), who is said to have changed his clothing at a critical point in the Zborów battle of 1649, during the Khmelnytsky Uprising, when Ukrainian Cossacks and their Crimean Tatar allies fought against the Polish-Lithuanian Commonwealth. At one point, while cheering on the Polish troops to hold ground, the king changed from French into Polish dress. After the settlement with the hetman of the Cossacks was signed and the king had returned to Warsaw, he went back to wearing French clothes, again to the displeasure of the szlachta. ${ }^{34}$

The question of visual belonging to the Polish szlachta must have been even more serious for foreign kings elected to the Polish throne. To win the favor of the szlachta, these monarchs used their image in a particular way. A remarkable illustration of this phenomenon is a portrait of August III from Saxony painted by Louis de Silvestre (1737) (Figure 4). August III is presented in Polish clothing, wearing a red kontusz with lapels, a żupan tied with a sash

32 Walter Leitsch: Strój i naród w Polsce w trzeciej tercji XVII wieku, czyli jak spodnie nabrały znaczenia politycznego, in: Barok. Historia-Literatura-Sztuka 12 (1999), 11-31, esp. 18-19.

33 Ibid., 17-18.

34 Jan. K. Ostrowski: Myśli o portrecie staropolskim, in: Anna Marczak-Krupa (ed.): Portret. Funkcja - forma symbol, Materialy sesji Stowarzyszenia Historyków Sztuki, Toruń, grudzień 1986. Warsaw 1990, 171-185, esp. 174. 


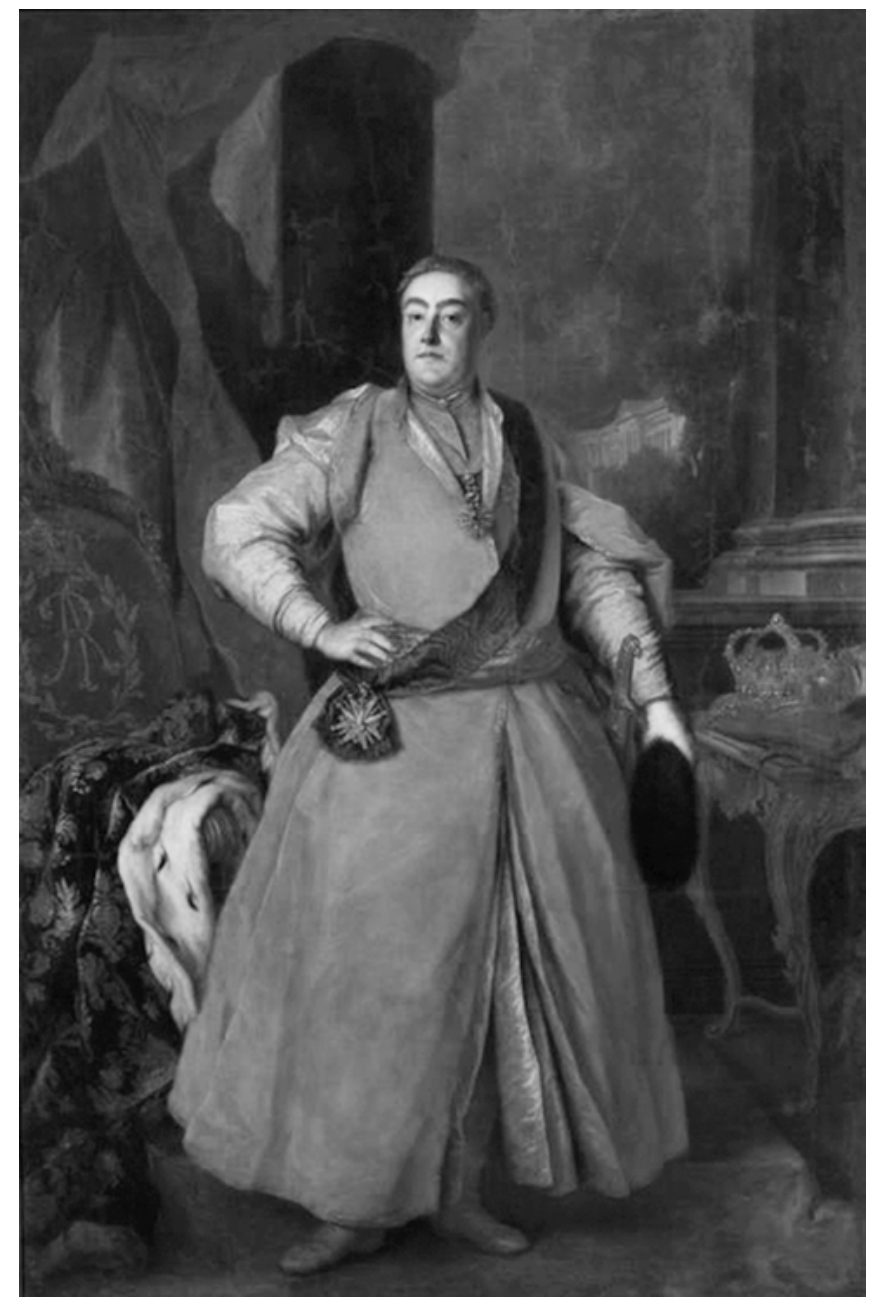

Figure 4: Louis de Silvestre: Portrait of King Augustus III in a Polish costume, c. 1737, National Museum in Cracow.

and a ribbon with the badge of the White Eagle order; in addition, he has a star of the White Eagle order on his chest and a Golden Fleece order on his neck. His hair is cut in accordance with Polish fashion. Before him, August III's father, August II, had also utilized portraits that styled him as a Polish nobleman, an image modeled on Jan III Sobieski and to the liking of the Polish szlachta.

While in the seventeenth century, in independent Poland, wearing a Polish costume expressed belonging to and self-identification with the 
szlachta, the eighteenth century, when Poland was divided, saw an increasing politicization of dress and fashion. The presence of Western fashion, perceived as foreign to Poland, was a point of heated dispute in the worldview of Polish elites, as disagreements over frock or kontusz, wig or moustache, entered the language of politics. Used as an identifying sign of "true patriots", traditional Polish costume enriched the repertoire of images that were drawn upon in ideological and patriotic disputes, far beyond the question of szlachta identities alone. The choice of clothing became an element of political play, as is finely illustrated by the example of Jan Potocki, who in 1788 planned to gain a seat in the Sejm as a delegate of the Poznań voivodeship. Potocki was raised abroad, and spoke better French than Polish. Nevertheless, he appeared in a kontusz, first at kontrakty, an annual local meeting of the szlachta in Poznan, then at a sejmik in Środa, eliciting an enthusiastic reaction among the szlachta (Figure 5). ${ }^{35}$ The decision to appear in what was perceived by members of the szlachta as both noble and patriotic dress was a well-taken step.

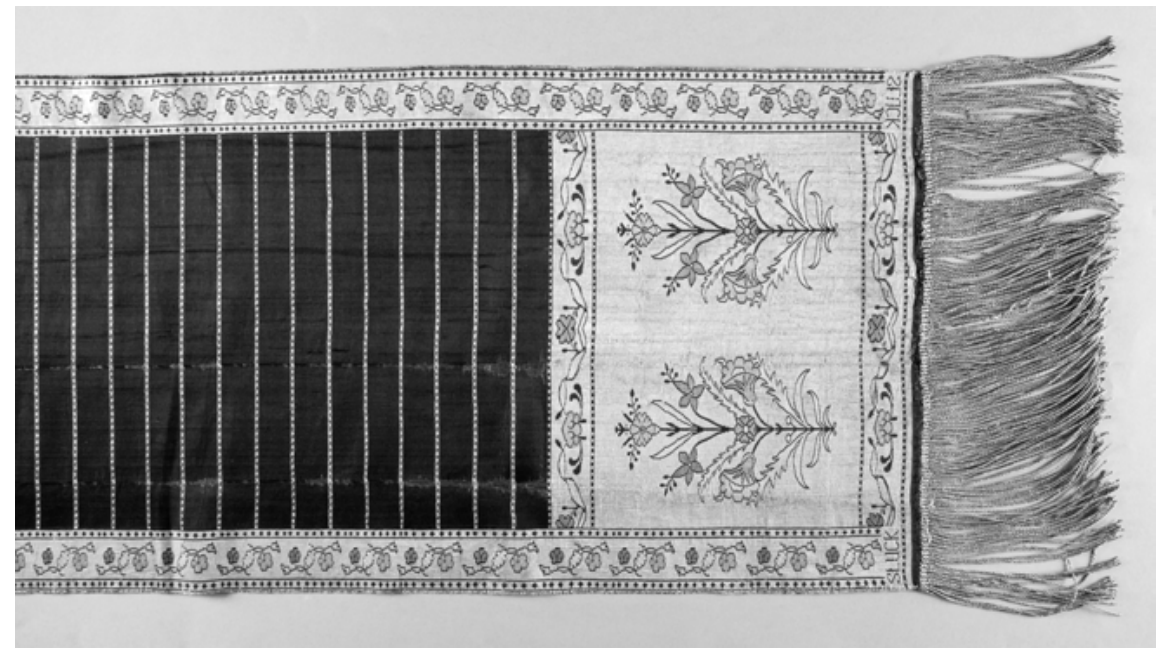

Figure 5: Kontusz sash, Słuck, c. 1780, National Museum in Cracow.

This new and more political perception of dress, however, did not mean that distinctions among members of the Polish nobility disappeared. The historian

35 Jarosław Dumanowski: Świat rzeczy szlachty wielkopolskiej w XVIII wieku. Toruń 2006, 194. 
Jędrzej Kitowicz notes that the magnates did not know how to stand out from the common crowd of nobility, because every time they created a new style or trend the szlachta immediately imitated it. ${ }^{36}$ A great illustration of this is the example of Piotr Sapieha (1701-1771), born in Dresden, voivode of Smoleńsk, owner of huge parts of land in Lithuania, and an heir of the Opaliński family and successor to their real estate in Great Poland. According to Kitowicz, Sapieha was since the years of his youth characterized by a love of tasteful and exquisite attire and was often very irritated by the szlachta's tendency to imitate his clothing. On one occasion, he ordered a czechman, a long overcoat with sleeves, sewn from white multan (a light woolen textile of long, fluffy hair), lined with blue velvet and with an order badge attached to it. ${ }^{37}$ Sapieha managed to present himself brilliantly in Poznań courts, being the only one wearing a multan white czechman with an order badge. But when he came to the courts the next time almost all the noblemen of Poznań were wearing multan czechmans, hemmed if not completely lined with velvet. "And he was even more surprised, when this year in Warsaw he saw plenty of multan czechmans. He presented his own to the cook; and immediately multan czechmans from the lords have gone to the stablemen and administrators."38

\section{The Perception of the Polish National Costume in the Eighteenth Century}

The Polish national costume gained its final shape in the middle of the eighteenth century. It still bore political meaning, as it distinguished the members of the nobility, the estate whose leading role in the state was manifested in the election of kings and in the liberum veto rule that gave each member of the noble assembly the right to nullify any legislation. During skirmishes between the szlachta and the Saxon army in 1715, clothing was seen as an expression of national, ideological, and religious identity: "nobody who wore a German garment could have been sure of his life." ${ }^{39}$ The increasing influence of Western fashion on the Polish

36 Jędrzej Kitowicz: Opis obyczajów za panowania Augusta III, vol. 2, ed. by Roman Pollak. Wrocław 2003, 528.

37 Irena Turnau: Stownik ubiorów. Tkaniny, wyroby pozatkackie, skóry, broń i klejnoty oraz barwy znane w Polsce od średniowiecza do początku XIX w. Warsaw 1999, 119.

38 Kitowicz, Opis, 528-529.

39 See Józef A. Gierowski: Między saskim absolutyzmem a złota wolnością. Z dziejów wewnętrznych Rzeczypospolitej w latach 1712-1715. Wrocław 1953, 303. 
szlachta was accompanied by a tempestuous discourse about the role of clothing in upholding the tradition of the nobility and in defining national identity. Already in the second half of the seventeenth century, the poet and satirist Wacław Potocki (1621-1696) had described the presence of foreign attire in the szlachta's wardrobe in a very negative light: "We have renounced everything along with our ancestors' dress, when we covered ourselves in foreign [dress] out of contempt [for our tradition]. ${ }^{30}$ The acceptance of foreign fashion in this way was perceived as being contrary to the essence of Polish nobility: to history, tradition, and the ancestral cult. It would have evoked the outrage of the ancestors if they could have seen it. The author and poet Jakub Kazimierz Haur wrote in his "Ekonomia ziemiańska" ("The economy of landed noblemen"): "As then the old good habit dies, the same way new fashions of today's century are raised, as often and everywhere they change into different shape, model, and kinds not stolid. If people of old rose from the dead, they would gather that mad Shrovetide ceremonies are constantly held in this world." ${ }^{41}$

The contemporary historian Jędrzej Kitowicz (1728-1804) presented a detailed account of eighteenth-century costumes: "At the beginning of the rule of Augustus III (King of Poland 1733-1763) few gentlemen wore foreign attire, except for members of Czartoryskis' house, Lubomirski, the Voivode of Krakow, and a couple of others, who already under Augustus II (1670-1733, elected King of Poland 1697-1706, 1709-1733) had switched to German attire.” Though the Saxon court was dressed according to French fashion at the time, it was perceived as German fashion in Poland. The same author further relates how during the coronation of Augustus III all participants were dressed like the king, according to the Polish fashion. Nevertheless, immediately after the ceremony, when the king put on "German" clothing again, Polish aristocracy immediately changed into Western European fashion. ${ }^{42}$

During the time of the Four-Year Sejm the question of a uniform for the nonexistent army was discussed, prompting interesting reflections of the satirists: "What do sharovary [a wide kind of trousers, associated at that time in Poland with Turks or Cossacks] have in common with the Polish heart, or does one put on and take off vices along with clothes [...]. Does a cubit of cloth make one braver?" ${ }^{43}$ On the other hand, the problem of proper dress for the Polish nobility

\footnotetext{
40 Quoted from: Jan S. Bystroń: Dzieje obyczajów w dawnej Polsce wiek XVI-XVIII, vol. 2. Warsaw 1933, 443.

41 Quoted from: Ibid.

42 Kitowicz, Opis, 475-478.

43 Irena Turnau: Rozwój ubioru narodowego od około 1530 do 1795 roku, in: Kwartalnik Historii Kultury Materialnej 34 (1986), 413-424, esp. 417.
} 
was important enough to be taken up by satirical Sarmatian writers of the eighteenth century, who ridiculed foreign fashion. A nobleman who submitted to the demands of foreign fashion was described as being like an eagle turned into an owl: "Oh, youth you are fashionable so! / Long kontusz cut to frock / Barber sprinkled head with powder / Made him such an ugly cut." ${ }^{44}$ In the eighteenth century, the szlachta wanted to limit travel and legally prohibit young people from going abroad, "because those who came back from these voyages seemed as though they were members of some other nation". ${ }^{45}$ This generational change was reflected by inventories, such as that of Biechów chatelain Bartłomiej Szołdarski and his son Ludwik from 1755. The father owned only national clothing and the son only Western dress, wigs, and stock ties. The chatelain's parade ensemble consisted of a crimson kontusz lined with stoat fur and a pink satin zupan, while for grand occasions the son wore a non-sheared velvet dress with golden loops braided along the ribs, a white vest decorated with silver and with golden buttons, and blue velvet trousers with golden buttons. ${ }^{46}$

This development implied not only a generational but also a social change. The gradual rejection of Sarmatian fashion in favor of Western European fashion during the eighteenth century implied a social devaluation of Sarmatian ideology. Among members of the szlachta who favored Western fashion, the kontusz became a costume for servants, a livery. This was the case, for example, among the servants of the Czernichów voivode Józef Potulicki at an early point in $1735 .{ }^{47}$

Satirists and moralists criticized the abandonment of national dress, and prophesied that the foreign fashion would bring along with it cultural practices from Spain or Italy. Some thought that the disappearance of the kontusz ensemble would cause the disappearance of the Polish language as well. ${ }^{48}$ Stanisław Witkowski, a poet and satirist active in the early seventeenth century, wrote: "Today you cannot recognize a Pole anymore; Italians, Frenchmen, / All over the princely courts, the Polish language is sure to perish. / The common garments are to perish too, because today stradyjoty, / Rubany, such capes with golden lace, / Saltebrety, kolety and other inventions."49

44 Zbigniew Kuchowicz: Obyczaje staropolskie XVII-XVIII wieku. Łodź 1975, 252-253. English translation by Maciej Walasek.

45 Sowa, Fantomowe, 265.

46 Dumanowski, Świat, 200.

47 Ibid., 192.

48 Janusz Tazbir: Kultura szlachecka w Polsce. Rozkwit-upadek-relikty. Poznań 1998, 45.

49 Stanisław Witkowski, Złota Wolność Koronna Seymom y Ziazdom na potomne czasy shiżąca. Z Deklaracyą krótką ku zatrzymaniu Staropolskiey Wolności po zawarciu Zgody y Miłości Braterskiey przez Seym Warszawski w Roku 1609. Cracow 1609. n.p. Stradyjota/stradyjotka, ruban, saltebret/ saltembret and kolet are garments. 
During the reigns of Augustus II and Augustus III, Polish costume was long, nearly to the floor. After the middle of the eighteenth century it changed markedly. Kontusz and zupan became shorter, reaching only slightly below the knees. Details of the dress also changed: the sleeves became much wider and longer, and wider-split. Near the end of the eighteenth century the details of the kontusz style changed again, giving the costumes a rather modest, classical look. Shirt collars appeared which covered the żupan's collar; shirt cuffs emerged from the żupan sleeves. These changes were modifications of the cuts' details, which resulted from general changes in Polish male fashion. However, the kontusz and $\dot{z}$ upan did not disappear, but still kept their position as basic elements of the szlachta dress. Over all these periods winter dresses, called first szuba or delia, then bekiesza and later kierezja or opończa, were made of fur, often lined with velvet, typically crimson in color, and tied under the neck with a thick silver or golden string.

Polish dress and its adaptations to western fashion also drew the attention of foreigners, who recorded their impressions in their memoirs. Foreigners saw a lack of taste and unfamiliarity with the rules of elegance in the Polish habit of freely combining Polish and foreign fashion. Nathaniel William Wraxall (1751-1831), an English diplomat and traveler, described Polish dress as follows: "There is something martial, rude, and characteristic in the Polish habit, which by no means displeases. It breaks that tame and insipid uniformity of external appearance, which, in the course of the present century, has almost entirely supplanted the ancient national distinctions of Europe."50 Another foreigner visiting Poland, Friedrich Schulz, a traveler from Livonia, noted that

saber, smallsword, jacket, French dress, national dress and frock, haircut and style, headdress or hat, everyone puts on what they like, these things are even mixed in the weirdest way. Often younger and older people of high estates are seen in a round hat, haircut, sharovars, English frock and French smallsword; or Polish saber, French attire, embroidered vest [...] nankeen trousers and English shoes with leggings; or finally English frock, vest, leather trousers, bootees with garters, head curled all over and a Polish four-edged hat on it. These are peculiarities that no one is offended with here, even though they show a lack of taste and the greatest negligence. ${ }^{51}$

50 Nathaniel William Wraxall, Memoirs of the Courts of Berlin, Dresden, Warsaw and Vienna in the years 1777, 1778, and 1779, vol. 1. London 1800, 399-400.

51 Fryderyk Schulz: Podróże Inflantczyka z Rygi do Warszawy i po Polsce w latach 1791-1793. Warsaw 1956, 246. 
An example of such a combination can be found in a portrait of the Kalisz voivode Ignacy Działyński from around 1765. He is wearing a kontusz and a żupan combined with a wig on his head. ${ }^{52}$

\section{Social Distinction and Dress Regulation}

From the sixteenth to the eighteenth century, clothes were valuable movable property. ${ }^{53}$ They were usually placed at the beginning of post-mortem inventories or right after silverware and jewelry. Polish researchers, especially since the 1950s, have made frequent use of the inventories as a source for the history of material culture. Among the surviving documents are inventories of possessions of noblemen as well as burghers and even peasants. Historian Jarosław Dumanowski has studied items listed in the inventories focused mainly on szlachta from Greater Poland, and based his publication on 300 inventories. $^{54}$ Alicja Falniowska-Gradowska in turn published 41 last wills of szlachta from Krakow from the years 1650 to $1799 .{ }^{55}$ The descriptions of the clothes in the inventories usually include the origin of the textile and its color, for which a very rich vocabulary was used, drawn for example from the world of cuisine (cinnamon, pepper, rosemary, caper, olive, clove, orange, peach, and lemon). This kind of description was closely connected with the formation and defense of an elite identity for the szlachta, for whom the abundance and variety of spices was a defining feature of elite old Polish cuisine, resistant to French culinary influences. ${ }^{56}$ Use of porcelain resulted in the appearance of the word "porcelain" from the middle of the eighteenth century to name a certain shade of white textile. Such colors alluded to the common feasting of the Polish nobility, an element of an insider, initiate culture. But for a long time it was crimson and

52 Barbara Dolczewska: Galeria portretów rodzinnych w Kórniku. Obrazy z XVII i XVIII wieku, in: Pamiętnik Biblioteki Kórnickiej 25 (2001), 267-292, here 286-287.

53 See: Ibid., 284; Andrzej Pośpiech: Miejsce ubioru w wielkopolskich pośmiertnych inwentarzach szlacheckich XVII wieku, in: Kwartalnik Historii Kultury Materialnej 34 (1986), 433-449.

54 Dumanowski, Świat. An extensive query of the inventories was also done by Irena Turnau when she was working on the book "Ubiór narodowy".

55 Alicja Falinowska-Gradowska (ed.): Testamenty szlachty krakowskiej XVII-XVIII w. Wybór tekstów źródtowych z lat 1650-1799. Cracow 1997.

56 Dumanowski, Świat, 185. A characteristic feature of szlachta customs was the significance given to the formulation of all forms of outside presentation, including clothing and jewelry. It was an existence based on a model of a spectacle - hence the appreciation of fashion, spectacular enterprises and feasts: Sowa, Fantomowe, 267. 
shades of red that were held in greatest favor for the clothing of the szlachta. In the invaluable seventeenth-century memoirs of Jan Chryzostom Pasek, marshal of the Rawa Sejm and chamberlain of the Krakow land, there is an anecdote about a Ruthenian man captured during battle by Pasek, who was wearing a grey kontusz at the time. The prisoner, later seeing another Pole wearing a crimson kontusz - despite the attire being worn out - preferred to be taken by him, whom he understood to be more prominent because of the color of his dress. ${ }^{57}$

In the eighteenth century every member of the szlachta owned at least one set of parade clothes, which indicated the estate to which he belonged. A poorer nobleman could give up furniture, glassware, and books, but he had to have his national dress. There appears to be a great gap between stereotypes of the Polish nobility's lavishness and ostentation in dress and the reality expressed in the inventories. The inventories scrupulously list also items of clothing that are tattered, worn-out, old, threadbare, moth-eaten, or re-sewn. The szlachta paid close attention to how others looked and closely guarded its exclusivity, but Adam Gdacjusz, a seventeenth-century preacher, noted: "We see what excesses there are in dress, one cannot see who is a nobleman, who is a burgher, who is a merchant, and who is a craftsman." 58

Clothing, which was one of the most valuable elements of the szlachta's movable property, was typically inherited from generation to generation..$^{59}$ It helped form intergenerational bonds and traditions. Leaving a garment in a last will could be a part of familial strategy, as there are instances of clothes being given by a grandfather to a grandson, like in the case of Kazimierz Strobiszewski, a nobleman, who bequeathed a kontusz in green and navy blue to his grandson, as he was in conflict with his son and thus appointed also his grandson as successor. Clothing remained valuable well into the eighteenth century, especially after the destruction and pauperization caused by war in its early decades. That changed, however, at the end of the century, when items were deemed "old" after several years. Clothing lost its value as a tool of intergenerational communication. ${ }^{60}$

During the Sejm of 1776, which introduced a number of reforms, an attempt was undertaken to codify outward appearance, and it was recommended that noblemen in each voivodeship decide on a uniform dress, to be made of domestic cloth, that would serve to distinguish each region's deputies. This attempt was part of wider reforms aimed at limiting excessive luxury

57 Jan Chryzostom Pasek: Pamiętniki, ed. by Roman Pollak. Warsaw 1987, 63.

58 Bystroń, Opis, 454.

59 Dumanowski, Świat, 203.

60 Ibid. 
in dress, which was deemed immoral and wasteful, in line with the European Enlightenment's critique of luxury. The regulations were tightened in 1780, but even then the szlachta was not particularly limited. Textiles deemed acceptable included Gros de Tours, cheap silks, satins, gauzes, muslins, and blond laces. In a novel by Michał D. Krajewski from 1785, the protagonist wears the voivodeship uniform of a different voivodeship every day, thus satisfying his need for splendor. ${ }^{61}$

Though the Sejm's resolution did not define the details of the uniforms and did not make them mandatory, individual local assemblies almost immediately selected their own colors for kontuszes, żupans, and sashes. The Sejm of 1778 saw the gentlemen already in their voivodeship uniforms. Some voivodeships (e.g. those of Brześć-Kujawy and of Inowrocław) introduced also separate Sejm uniforms, different from those worn at the local assemblies. In 1778, an amaranthine kontusz and a white żupan, silver epaulets with gold and with colored fringes on the left shoulder were obligatory in the Krakow voivodeship; two years later the kontusz was to be navy-blue with an amaranthine collar and a żupan of the same color. Hats with quadrilateral head and fur trim were worn with the voivodeship uniforms. On the other hand, knights of the two most important orders (White Eagle and Saint Stanislaus) wore red-and-white or whiteand-crimson ensembles. The law on voivodeship uniforms was confirmed by the Sejm in 1780, which at the same time prohibited the use of any decorations with them.

These considerations concerning national dress during the second half of the eighteenth century, and especially during the Four-Year Sejm (1788-1792), despite the previous leaning towards Western fashion, were an indication of the rise of patriotic attitudes in the troubled country. The national dress was now worn not only by the magnates and the szlachta in general, but also by the bourgeoisie in the capital and in smaller towns, who wore kontuszes and zupans, even though they were not allowed to wear a sash tied on a kontusz like the szlachta. ${ }^{62}$ The regulations of the Sejm were supposed to stop the spread of Western fashion. These attempts were surely unsuccessful, and, moreover, some of the voivodeship uniforms were given the shape of western attire. Such was the case with Wschowa chamberlain Józef Radoliński, who owned seven voivodeship uniforms, all of them three-part ensembles consisting of a uniform,

61 Michał D. Krajewski, Woyciech Zdarzyński, życie i przypadki swoje opisuiący 15. URL: https:// wolnelektury.pl/katalog/lektura/krajewski-woyciech-zdarzynski-zycie-i-przypadki-swoje-opisuiacy. html (30 Sept. 2018).

62 Turnau, Rozwój ubioru narodowego, 417; Małgorzata Możdzyńska-Nawotka: O modach i strojach. Wrocław 2005, 82. 
a vest, and trousers. The second camlet uniform of the voivodeship came with a vest and goose-skin trousers. ${ }^{63}$ The change of national dress into foreign in the second half of the eighteenth century was also a generational change; the youth dressed in accordance with Western fashion, despite attempts to turn the traditional dress of the szlachta into a patriotic attire.

\section{National Dress at the Time of the Partition of Poland}

Apart from kontusz and żupan, new items that were viewed as national dress emerged during the nineteenth century, for example the czamara, a long garment often lined with fur and decorated with braiding, and the sukmana, a peasant's coat made of woolen cloth. Participants in the Polish uprisings were not indifferent to the problems of fashion: during the November uprising of 1830-31 the czamara gained patriotic meaning. "Warsaw man/Took off the frock/Against the czar/There is czamara", wrote Polish poet and independence fighter Rajnold Suchodolski. ${ }^{64}$ When the national bard Adam Mickiewicz wanted to describe a defender of the homeland, he wrote that for "the soldiers of homeland uprising" only czamara were fitting and not red French hats, English ermines, or German togas and berets. "You shall wear insurgents' czamary, you old and young; because you are all soldiers of the homeland uprising. As in Polish czamara is a name of the dying man's clothes. And many of you will die in the insurgents' clothes. And all of you shall be ready to die." 65 The stock of national dress was further augmented by the peasant's coat, the sukmana, which had already gained importance during the time of the Kościuszko uprising in 1794. Even earlier, in the time of the Bar Confederacy of 1768, the confederate hat had become popular. ${ }^{66}$ When the Polish nation in its modern form first began to emerge in the nineteenth century, the kontusz

63 Dumanowski, Świat, 199.

64 Tazbir, Kultura szlachecka, 45.

65 "Wy noście Czamary powstańskie, i starsi, i młodsi; bo wszyscy jesteście żołnierzami powstania Ojczyzny. Czamarą zaś nazywa się po polsku strój, w który ubiérano umierającego. A wielu z Was umrze w stroju powstańskim. Wszyscy zaś niech będą gotowi umrzéć.” Adam Mickiewicz, Księgi narodu polskiego i pielgrzymstwa polskiego. URL: https://wolnelektury.pl/katalog/lektura/ ksiegi-narodu-polskiego-i-pielgrzymstwa-polskiego.html (4 Dec. 2018); Zofia Stefanowska (ed.): Swojskość i cudzoziemszczyzna w dziejach kultury polskiej. Warsaw 1973, 211.

66 Maria Molenda-Berkowicz: Moda w czasach konfederacji barskiej, in: Zeszyty spiskosqudeckie 3 (2008), 89-94, esp. 92. 
ensemble, which belonged mostly to the szlachta in the days of the PolishLithuanian Commonwealth, turned into a symbol of belonging to the newly imagined Polish nation. In the time of Galician autonomy, for example, it was eagerly worn by the bourgeoisie, particularly in Krakow.

The nineteenth century saw a renaissance of the Sarmatian idea. The threat of the Russification and Germanization of the local population in the partitioned territories by the neighboring empires made people look to the past for support. Sarmatism served as firm ground for an endangered tradition in the time of the motherland's bondage. This tradition gained special meaning after the defeat of the November Uprising in 1831, when the wearing of national costumes was prohibited by law, most strictly under Russian and Prussian rule. ${ }^{67}$ Thus, wearing the kontusz costume became a form of patriotic demonstration; the kontusz ceased to be daily attire. At the same time the czamara turned into a symbol of national grief: a long simple, dark-colored dress, with braiding as the only decoration. Only in Galicia, under Austrian rule, did the citizens of Krakow receive from the Emperor Franz Joseph I in 1861 the privilege of carrying a karabela with the "full ancient Polish costume, consisting of the outer clothing called kontusz and the lower called zupan”. Four years later an analogous privilege was extended to the citizens of Lwów. Kontusz costumes were ordered and worn at traditional national celebrations, at sessions of parliament in Lwów and Vienna, and during weddings, family congregations, and jubilees. ${ }^{68}$ The kontus $z$ costume became an icon, but was not worn as casual dress.

\section{Conclusion}

The development of a national dress of the Polish nobility continued throughout the early modern period and saw several modifications and changes. The form of the particular Polish dress was influenced by the Sarmatian tradition and by the incorporation of textiles and styles from the East, mostly the Ottoman Empire. The early modern dress of the Polish nobility was also characterized by the desire to distinguish itself from other European nations. In its different forms, materials, and embellishments, it was also a means of expressing high status and wealth, both in the context of the whole society and within the szlachta, despite the declared and theoretical equality of Polish nobility. This attire displayed the splendor of the wearer and became one of the symbols

67 Adam Buława: Pejzaże konspiracji. Kod patriotyczny, in: Polityka 1 (2013), 37- 45.

68 Turnau, Ubiór, 162. 
determining and presenting the essence of the character and worldview of the masculine part of Polish nobility.

By the eighteenth century new garments like the czamara and the sukmana were incorporated in the national dress as a way to display patriotism. In the second half of the eighteenth century the national costume, apart from being a symbol of belonging to the nobility, gained patriotic value under the worsening political conditions of the country. This patriotic significance was especially important during the time of the partitions, when wearing these specific garments was an evident manifestation of Polish patriotism. Their nature, however, had already changed, and they were more of a costume, a symbolic outfit, than an everyday dress. 